\title{
Risky Signals: The Political Costs of Exchange Rate Policy in Post-Communist Countries
}

\author{
Tanya Bagashka \\ Randall Stone
}

\begin{abstract}
It can be risky for governments to renege on exchange rate commitments, but it is misleading to characterize the costs as audience costs. While an audience costs approach assumes that the punishment for reneging is automatic, we model the choice of exchange rate policy in the shadow of elections as a signaling game between voters and governments, where governments have private information and voters are rational. We find that voters draw different inferences when they see reneging by different actors, and only Left governments are punished for breaking their promises. We test this hypothesis in the context of the post-Communist countries in the 1990s, and find that Left governments were more likely to fall if they reneged on exchange rate commitments, but Right governments were not.
\end{abstract}




\section{Introduction}

In the 1990s, many post-Communist countries publicly committed to fixed exchange rates, or to various forms of exchange rate targeting, such as bands and crawling pegs, in order to gain credibility with voters and investors. These commitments were particularly attractive to the Left, which suffered from a reputation for inflationary policies (Bodea 2008; Walker 2009). There is some evidence that these commitments promoted capital inflows, and in some cases, foreign direct investment. Exchange rate commitments were frequently abandoned, however. This empirical pattern of frequent commitments and frequent reneging poses several questions. If commitments are frequently broken, do they nevertheless convey information about a government's policy intentions? If so, what makes them informative? Do voters punish governments for breaking their public commitments, and if they do, why do they? Is it appropriate to model this as automatic audience costs (Frankel 2005; Leblang 2005), or do we learn something important by analyzing voters' strategic incentives?

Audience costs are non-strategic, automatic penalties imposed on the leader by the public when a particular action is taken. They have no micro-foundations: the analyst does not attempt to model why it is rational for the public to impose them (Fearon 1994; Schultz 2001; Ramsay 2004 criticizes this approach). Rational publics may not automatically impose audience costs; they should draw inferences from what they observe and act appropriately.

We argue that, if voters are rational and exchange rate commitments are tools for governments to signal their preferences for sound macroeconomic policies, the political costs of breaking such commitments should be conditional on government partisanship. It is generally believed that Left governments suffer from greater credibility problems in macroeconomic policy making than Right governments. If this is the case, voters should 
interpret reneging on commitments differently depending on whether it is done by Left or Right governments. Voters have different priors about Left and Right governments, so they draw different inferences from the policies that they observe. As the Left is more prone to inflationary policies, voters, uncertain about both economic fundamentals and the government's policy preferences, should attribute reneging by a Left government to its traditional policy preference rather than to exogenous shocks. On the other hand, when a Right government breaks an exchange rate commitment, voters are likely to conclude that the policy change was due to something they did not know about the policy environment, rather than infer that the government is soft on inflation. As a result, a government of the Left should suffer disproportionate political costs when it reneges. If, conversely, the costs of breaking exchange rate commitments are automatic audience costs, policy-makers should be punished regardless of partisanship.

We develop a model of exchange rate policy, examining the problem of incomplete information about government preferences over economic outcomes and the signaling effects of exchange rate choices. According to our results, Left governments are less likely to break exchange rate commitments, but are punished disproportionately when they do so. As Left governments are faced with inflationary expectations on the part of voters and investors, they suffer greater reputation costs when defecting than Right governments, which are traditionally more concerned about keeping inflation low. When a Left government breaks an exchange rate commitment, voters update their beliefs to place the government further to the left. Since Left governments are already expected to be to the left of the median voter, this increases their probability of losing office. Conversely, devaluations move beliefs about Right governments, which are perceived by voters as more concerned with inflation than with unemployment, closer to the median voter, which decreases the probability that they lose office. We test the empirical implications of the model in the context of the post-Communist countries in the 1990-2001 period. Our results provide evidence in support of the signaling hypothesis. 


\section{Partisanship and Exchange Rate Policy}

In the 1990s, exchange rate commitments were frequently adopted and frequently broken in post-Communist countries. Commitments were broken by devaluing the announced parity, by moving from a peg to a crawl, or by widening the fluctuation band of the cur-

rency (see Table 1). A similar empirical pattern is observed in other developing countries (Klein and Marion 1994). Within the group of countries that had pegged their exchange rates against any currency for at least five years as of June 1995, “...aside from some small tourism economies, oil sheikhdoms, and highly dependent principalities, there is literally only a handful of countries that have continuously maintained tightly fixed exchange rates..." (Obstfeld and Rogoff 1995). Reneging on commitments to maintain fixed exchange rates is common, despite growing evidence of its high political costs (Cooper 1971; Frankel 2005; Leblang 2005).

Several studies have found that breaking de jure exchange rate commitments is politically risky. According to Bernhard and Leblang (2002), British incumbents suffered large losses in public opinion after unanticipated depreciations. Cooper (1971) finds that governments that devalued were twice as likely to fall within 12 months as those in a contemporaneous control group. In a sample including 103 countries in the 1971-2003 period, Frankel (2005) finds that in developing countries, devaluations that broke public promises increased the likelihood that an executive loses office within one year by 45 percent. The effect was even stronger within six months of the devaluation episode: a currency crash doubled the likelihood that an executive loses office (Frankel 2005). Leblang (2005) studies the effect of breaking a de jure exchange rate commitment on the duration of leaders across 124 countries in the period 1973-1999 and finds that abandonment of an exchange rate peg decreases the probability of re-election by 60 percent. 
Why do governments adopt exchange rate commitments, if it is not optimal to keep such promises and breaking promises is politically costly? Why do voters punish governments for breaking their promises, if breaking the exchange rate commitment could be the optimal economic policy ex post? A possible explanation is that voters punish governments for poor economic performance: devaluations and currency crashes are often accompanied by sharp recessions. However, in many cases devaluations increase production and exports of tradable goods, reduce imports and boost the trade balance, GDP, and employment. The alternative of defending an overvalued exchange rate in the face of declining competitiveness, increasing risks of a financial crisis, and rising risk premia for borrowers is much less attractive. Furthermore, contraction, recession, declining reserves and job losses have not had the severe political consequences that have followed breaking public exchange rate commitments (Frankel 2005). What is it about breaking public exchange rate commitments that is so politically costly?

Although a substantial literature has focused on optimal exchange rate regimes as a function of the structural features of the economy (Bosco 1987; Dreyer 1992; Savvides 1990; Wickham 1985), the introduction of exchange rate commitments is usually driven by the need to build monetary credibility (Giavazzi and Pagano 1998). Under such circumstances, it is optimal for policy-makers to import credibility from an inflation-averse foreign central banker through the delegation of monetary policy. Fixed exchange rates are public and visible commitments that tie domestic monetary policy to that of a less inflation-prone country. They severely restrict the options available to policy-makers for achieving domestic political and economic objectives. Under fixed rates, governments cannot use monetary policy for external adjustment through appreciation and depreciation of the exchange rate and thus insulate the real economy from supply and demand shocks. While this reduces policy-makers' room to maneuver, fixed rates can resolve the government's credibility problems arising from time-inconsistent preferences and asym- 
metric information.

Absent the exchange rate commitment, policy-makers have an incentive to introduce surprise inflation after wages have been locked in, thus benefiting from increased output and employment (Barro and Gordon 1983; Rogoff 1985). In a rational expectations framework, the public understands that the government's optimal ex post strategy might differ from its optimal ex ante strategy and discounts the government's inflation announcements accordingly (Kydland and Prescott 1977). As a result, inflation is higher than the government would have adopted absent the credibility problem, without the benefit of increased output. By reducing the incentives for policy-makers to engage in inflationary policies, fixed exchange rates solve the policy-maker's time inconsistency problem and allow them to avoid inefficient equilibria (Giavazzi and Pagano 1998; Milesi-Feretti 1995).

Fixed exchange rates could also be a solution to credibility problems arising from asymmetric information. While in the previous case, the government lacks credibility because the public understands its time-inconsistent objectives, in this case the public is unable to tell what the government's true motivations or preferences are: is the government more concerned with inflation or with fluctuations in unemployment? As policy-makers have superior information about economic fundamentals, the public cannot tell whether deviations from announced policies reveal information about the government's true preferences, or are simply driven by exogenous shocks. Fixed exchange rates could allow a 'true stabilizer' to reveal himself. Under adverse economic circumstances such as high unemployment, a fixed exchange rate regime might be a signal too costly for a government that is 'soft' on inflation to implement (See Backus and Driffil 1985; Flood and Isaard 1989; Lohmann 1990; Drazen and Masson 1994; Cukierman and Tommasi 1998).

A natural corollary to the credibility argument is that a government's credibility gains from fixing should depend on its partisanship, but it is not a priori clear which way 
the causal relationship should run. Theory and empirical evidence have highlighted the different priorities of the Left and the Right, namely, the Left's preference for low unemployment and the Right's concern for maintaining low inflation (Hibbs 1977; Alvarez, Garrett, and Lange 1985; Garrett 1995; Garrett and Lange 1995; Iversen 1999; Oatley 1999; Franzese 2002). Recognizing these different priorities, Simmons (1994) argues that governments of the Left should give up fixed exchange rates more frequently as markets tend to mistrust them disproportionately. However, as Bodea (2008) notes, if Left governments enjoy disproportionate credibility gains from fixed rates, they may be more loath to abandon them in bad times than the Right. It is not obvious which way the relationship ought to run, which suggests a need to model this interaction formally.

There are several ways in which partisanship might interact with exchange rate policies. Pegged rates could be a device to 'tie the hands' of subsequent governments and thus allow policy-makers to affect future economic policies (See Persson and Svenson 1989; Alesina and Tabellini 1995). This would imply that right-leaning governments choose exchange rate commitments in order to constrain their left-leaning successors. To the contrary, Milesi-Feretti (1995) shows that, if fixed exchange commitments are irrevocable and voters expect inflation to be higher for Left governments than for Right governments when the exchange rate floats, a Left incumbent government would reap electoral gains from fixing. On the other hand, if there is an election bias in favor of the Right under flexible exchange rates, by committing to fixed exchange rates a Right incumbent would solve the Left's greater time-inconsistency problem and thus benefit its political rival. In a broader framework, Cukierman and Tommasi (1997) show that, if the uncertainty about the state of the world is greater than the uncertainty about changes in the government's policy preferences, an incumbent might improve her re-election prospects by proposing a policy that contradicts her traditional policy position. In the context of exchange rate policy, a fixed exchange rate commitment would benefit only a Left incumbent, as such a policy is inconsistent with its emphasis on keeping unemployment low. According to both 
of these arguments, an irrevocable commitment to a fixed exchange rate would move the expected policy of a Left government closer to the preferences of the median voter and improve its re-election chances.

While these formal arguments imply that the Left should choose fixed exchange rates, they do so by assuming that such commitments are irrevocable and solve the time inconsistency problem (Milesi-Feretti 1995). It remains to be seen why the Left's preference for expansionary policy does not render such commitments incredible. However, coming at the puzzle from the opposite direction, empirical work has uncovered evidence that Left governments are, in fact, less willing than their Right counterparts to abandon exchange rate commitments. The successors to the Communist parties in Eastern Europe realigned less frequently following a public commitment to fixed exchange rates, even when markets tested their resolve (Bodea 2008, see also Table 1). Similarly, using a different data set and a different sample of countries, Leblang (2005, p. 548) finds that during electoral periods, Right governments were more likely to devalue, while Left governments were more likely to defend the exchange rate parity when there was a speculative attack. This suggests that, if exchange rate commitments are rendered credible by the political costs of reneging, these costs must vary systematically according to government partisanship.

Studies that conceptualize the political costs of breaking exchange rate commitments as audience costs fail to account for these partisan patterns. If the political costs of breaking exchange rate commitments were automatic audience costs (Fearon 1994), the Left and the Right should be equally likely to be punished by voters (Frankel 2005; Leblang 2005). In a rational voting framework, on the other hand, if governments use exchange rates to build credibility, as theory suggests, we should expect voters to treat Left and Right governments differently. If voters recognize the different macroeconomic priorities of the Left and the Right, they should interpret their defections from fixed exchange rate commitments differently. As the Left's priority is to maintain low unemployment, the public 
should expect Left governments to be more likely to be of the 'weak' (inflationary) type than Right governments. While both Left and Right governments might break commitments under adverse economic circumstances, when the incumbent is Left, voters should put a higher weight on the probability that reneging was due to inflationary preferences rather than to exogenous shocks. Hence, we argue that Left governments have stronger incentives to avoid breaking commitments because they are punished more than Right governments if they do renege under the same conditions. A preliminary empirical analysis is consistent with our claims: while left governments broke their commitments less frequently, they were disproportionately punished (see Table 1). The model that follows illustrates this logic, and subsequent statistical analysis tests it more rigorously.

\section{The Model}

Our model is a two-period game of incomplete information whose players are an incumbent government, a challenger, and voters. The government chooses an economic policy in the first period, an election is held, and the winner chooses a policy for the second period. Voters have a range of economic policy preferences, and voting is probabilistic. The government places value $b$ on holding office and has policy preferences that depend

on its type and a short-term shock. The government's type is $\omega_{J} \sim N\left(\mu_{J}, \sigma_{\omega}^{2}\right)$, where $\mu_{L}>\mu_{R}$, which implies that the Left $(J=L)$ has lower aversion to inflation than the Right (Alesina and Roubini 1992). The random shock, $\epsilon_{T} \sim N\left(0, \sigma_{\epsilon}^{2}\right)$, where $T$ denotes the time period, represents exogenous economic events that affect the attractiveness of alternative economic policies. For convenience, we denote $p_{\omega}$ and $p_{\epsilon}$ as the precision of $\omega_{J}$ and $\epsilon_{T}$ respectively, or the inverse of the variance. ${ }^{1}$ We postulate that the equilibrium choice of exchange rate policy $\pi_{J T}^{*}$ is the following linear function of $\omega_{J}$ and $\epsilon_{T}$ :

$$
\pi_{J T}^{*}=h_{J T}+k_{\omega J T} \omega_{J}+k_{\epsilon J T} \epsilon_{T}
$$


where $h_{J T}, k_{\omega J T}$, and $k_{\epsilon J T}$ are coefficients to be determined.

The sequence of events is as follows:

1. Nature selects a government of type $\omega_{J}$ and the shock $\epsilon_{1}$.

2. The government chooses a rate of devaluation $\pi_{J 1}$.

3. The public updates its beliefs about the government's type and decides whether to re-elect the incumbent or elect the challenger. If the incumbent is Left, the challenger is Right and vice versa.

4. The elected government chooses $\pi_{J 2}$. With this move the game ends.

The stage-game utility for the government is as follows:

$$
-\left(\pi_{J 1}-\left(\omega_{J}+\epsilon_{1}\right)\right)^{2}+b
$$

If the incumbent is not re-elected, he receives a second stage-game utility of $-l$, which is strictly negative.

In the first period, the incumbent chooses $\pi_{J 1}$ to maximize:

$-\left(\pi_{L 1}-\left(\omega_{L}+\epsilon_{1}\right)\right)^{2}+b+\delta P_{L}\left(\pi_{L 1}\right)\left(-\left(\pi_{L 2}-\omega_{L}\right)^{2}+b\right)+\delta\left(1-P_{L}\left(\pi_{L 1}\right)\right)(-l)$

where $\delta$ is the discount factor, $\pi_{L 1}$ is the devaluation rate in the first period, and $P_{L 1}$ is the probability of re-electing a Left incumbent given the policy she chooses in the first period. 
The utility of a type $n$ voter is given by $-\left(\pi_{J T}^{e}-c_{n}\right)^{2}$ where $c_{n}$ is the ideal point of voter $n$ and $\pi_{J T}^{e}$ is the expected policy in the second period. A random sample of voters cast votes, so the ideal point of the median voter is drawn from a distribution: $c_{m} \sim U(\underline{c}, \bar{c})$.

\section{Solution Concept}

The solution concept is perfect Bayesian equilibrium (PBE). PBE requires that (a) each player's choices be sequentially rational given her beliefs at the time of choice and the other player's strategy; (b) beliefs about the other player's type be consistent with prior beliefs, equilibrium strategies, and Bayes' Rule on the path of play.

\section{Proposition 1}

The following strategies form a Perfect Bayesian Equilibrium:

1. The incumbent chooses policy in the first period:

$$
\begin{aligned}
& \pi_{L 1}=\omega_{L}+\epsilon_{1}-\delta \frac{p_{\epsilon}}{4 h_{L 1}\left(p_{\omega}+p_{\epsilon}\right)}(b+l) \\
& \pi_{R 1}=\omega_{R}+\epsilon_{1}+\delta \frac{p_{\epsilon}}{4 h_{R 1}\left(p_{\omega}+p_{\epsilon}\right)}(b+l)
\end{aligned}
$$

2. Voters re-elect the incumbent with probability:

$$
P_{L}\left(\pi_{L 1}\right)=\frac{1}{2 h_{L 1}\left(p_{\omega}+p_{\epsilon}\right)(\bar{c}-\underline{c})}\left[2 h_{L 1} \bar{c}\left(p_{\omega}+p_{\epsilon}\right)-h_{L 1}\left(p_{\omega}+p_{\epsilon}\right) \mu_{R}-p_{\epsilon}\left(\pi_{L 1}-k_{L 1}\right)-h_{L 1} p_{\omega} \mu_{L}\right]
$$




$$
P_{R}\left(\pi_{R 1}\right)=\frac{1}{2 h_{R 1}\left(p_{\omega}+p_{\epsilon}\right)(\bar{c}-\underline{c})}\left[-2 h_{R 1} \underline{c}\left(p_{\omega}+p_{\epsilon}\right)+h_{R 1}\left(p_{\omega}+p_{\epsilon}\right) \mu_{L}+p_{\epsilon}\left(\pi_{R 1}-k_{R 1}\right)+h_{R 1} p_{\omega} \mu_{R}\right]
$$

3. The elected government chooses policy in the second period:

$$
\pi_{J 2}=\omega_{J}+\epsilon_{2}
$$

Proof: See Appendix 1.

\section{Comparative Statics}

Our analysis generates two comparative statics results.

1. Devaluation. Equilibrium inflation (devaluation) is lower for a Left incumbent. For a given government type and exogenous shock, equilibrium devaluation will be lower for a left-wing incumbent because $k_{L 1}=k_{R 1}=1$, but $h_{L 1}<h_{R 1}$.

$$
\begin{gathered}
h_{L 1}=-\delta \frac{p_{\epsilon}}{4 h_{L 1}\left(p_{\omega}+p_{\epsilon}\right)(\bar{c}-\underline{c})}(b+l) \\
h_{R 1}=\delta \frac{p_{\epsilon}}{4 h_{R 1}\left(p_{\omega}+p_{\epsilon}\right)(\bar{c}-\underline{c})}(b+l)
\end{gathered}
$$

This result is driven by strategic considerations. While the preferences of the Left are more inflationary than those of the Right, the desire for re-election, restrain the Left. 
2. Reelection. The probability of reelection is decreasing in the first-period policy for the Left government, and increasing in the first-period policy for the Right government. Voters have different priors about the inflationary preferences of the Left and the Right, so they draw different inferences from the policies they observe. Devaluing moves a Left government away from the median voter in expectation, but moves a Right government closer to the median voter in expectation. Consequently, voters are less likely to reelect a Left government after it devalues, and more likely to reelect a Right government after it devalues. This follows from Proposition 1, part 2 .

3. Implications for credibility. Voter's observation of the policy proposal $\pi_{J 1}$ given its knowledge of $h_{J 1}$ and $k_{J 1}$ is equivalent to an observation of $\omega_{J}+\epsilon_{1}=\pi_{J 1}-h_{J 1}$. We are interested in inferences about the unknown value of $\omega_{L}$ from the observation of $\left(\omega_{J}+\epsilon_{1}\right)$. This observation is a random drawing from a normal distribution with an unknown mean $\omega_{J}$ and precision $p_{\epsilon}$. The prior distribution over than unknown mean is $N\left(\mu_{J}, p_{\omega}\right)$. Using Theorem 1 of Section 9.5 of De Groot 1970, p.167), the posterior distribution of $\omega_{J}, f\left(\omega_{J}, \pi_{J T}\right)$ is $N\left(\omega_{J}^{\prime}, p_{\omega}^{\prime}\right)$, where

$$
\omega_{J}^{\prime}=\frac{p_{\omega}}{p_{\omega}+p_{\epsilon}} \mu_{J}+\frac{p_{\epsilon}}{p_{\omega}+p_{\epsilon}}\left(\pi_{J T}-h_{J T}\right)
$$

and

$$
\not{p}=p_{\omega}+p_{\epsilon}
$$

Recalling that $h_{L 1}<h_{R 1}$, it is easy to see that $\omega_{L}^{\prime}>\omega_{R}^{\prime}$ for all $\pi_{J 1}$. This means that any observed rate of devaluation $\pi_{J I}$ is interpreted by voters as associated with a stronger (posterior) type if the incumbent is Right than when the incumbent is Left. 


\section{Empirical Tests}

We test the empirical implications of the model in the context of the post-Communist countries in the 1990s. This choice of sample solves two potential inference problems. First, our theoretical argument applies only when voters have substantially different priors about the policy preferences of Left and Right governments. The model makes strong predictions in this sample, however, because the Left's credibility problem was particularly acute during the post-Communist transition. The socialist parties in Eastern Europe suffered from serious reputation problems as successors to the Communist parties, so they faced incentives to adopt fixed exchange rates in order to convince investors that they would adhere to sound economic policies (Bodea 2008). Information during the transition was scarce, and fixed exchange rates served as a visible and public commitment to buy credibility and gain access to international capital markets. Second, restricting the sample allows us to minimize measurement error on the key independent variable, partisanship. Studies of partisan politics have established that voters are able to rank parties on a left-right scale that has cross-national validity, but these rankings become imprecise when they are extended across regions and time periods. It is doubtful that socialism had the same meaning in Latin America in the 1980s and Eastern Europe in the 1990s, for example, and there is empirical evidence that Left parties behaved differently in these different contexts (Pop-Eleches 2009). Our empirical analysis tests two competing explanations for the high political costs of breaking exchange rate commitments: the audience costs explanation advanced by Leblang (2005), and the signaling argument developed here.

Audience Costs Hypothesis: Breaking an Exchange Rate Commitment should reduce the expected tenure of Left and Right governments equally.

Signaling Hypothesis: Only Left governments should be punished for breaking their exchange rate commitments. 


\section{The Dependent Variable: Government Duration}

Government duration is the number of months the current government has been in office. A government is coded as falling when the prime minister or the main party of the ruling coalition changes; the departure of a junior partner from a coalition while the prime minister and the main coalition partner remain the same, is not. ${ }^{2}$ The dataset covers the 1990-2001 period and includes 26 countries in Eastern Europe and the former Soviet Union. Our analysis does not extend to later time periods due to the lack of data on government partisanship. Stone (2002) codes governments from 1990 to 2001; this data has the unique advantage of providing information on observed economic policy commitments prior to assuming office. Extending the analysis to the post-2001 period is fraught with other difficulties. While the struggle between the anti-reform Left and pro-reform Right dominated political contestation in the early transition, recent empirical studies have shown that the Left has weakened and that the salience of the left-right dimension has diminished in some East European countries (Enyedi 2006, Markowski 2006a, 2006b). In Poland, for example, the post-Communist SLD's share of the popular vote dropped sharply in the 2005 parliamentary election. In addition, EU accession has constrained the macroeconomic policy options of applicant and member countries, thus making the post-communist countries a more heterogenous group, which would further complicate the analysis. ${ }^{3}$

\section{Main Explanatory Variables}

Breaking an Exchange Rate Commitment As Kaminski et.al. (1998) show, there are various ways to operationalize the concept of abandoning an exchange rate commitment. Most studies focus on crises such as large changes in the exchange rate (15\% or $20 \%$ ) or speculative attacks (See Klein and Marion 1994; Edwards 1989; Edwards and Montiel 1989; Frankel and Rose 1996; Eichengreen et.al. 1996; Krugman 1979; Bernhard and Leblang 1999). Our interest is not in devaluations per se, however, but in whether 
governments keep whatever commitments they make, because we want to know whether voters use this information to draw inferences about future behavior. Consequently, we code breaking a commitment as a deviation from a pre-announced policy. Following Bodea (2008), we treat all realignments as potentially entailing reputation costs. Even small realignments can signal to markets how much governments value exchange rates as disinflation instruments, and frequent and incremental realignments can be equivalent to devaluation or an outright abandonment of the fixed exchange rate. All of the following events are considered breaking exchange rate commitments when they surprise the public: devaluation of the currency, even if the country remains on a pegged exchange rate regime; transition between currency regimes, such as from pegs to crawls or pegs to bands; devaluation of the parity within the crawling peg or crawling band regimes; changes in the width of the fluctuation band; and changes in the foreign currency or the basket of currencies to which the domestic currency is pegged.The dataset includes only de jure exchange rate commitments and changes in the parameters of the arrangement that were not announced and specified when the arrangement was initially adopted. This coding is appropriate for our purposes, as we are concerned with the reputation effects of exchange rate policy. If a government maintains a de facto fixed exchange rate regime but does not publicly announce it, there is no reason to expect it to suffer reputation costs from realignments. There are 16 episodes in the data for Left governments and 36 episodes for Right governments that fit our definition of breaking an exchange rate commitment (see Table 1). This is consistent with Bodea's (2008) and one of the implications of the theoretical model, namely, that Left governments are less likely to break their commitments. The following countries adopted exchange rate commitments: Poland (January 1990-December 1999), Hungary (January 1990-December 1999), Czechoslovakia (January 1991-December 1992), Czech Republic (January 1993-May 1997), Slovakia (February 1993-October 1988), Ukraine (March 1997-August 1999) and Russia (July 1995-August 1998). ${ }^{4}$

[Table 1 about here.] 


\section{Left-right Government Partisanship}

To capture the influence of partisanship of the government and the legislature, we include an ideological score. In terms of the theoretical model, the trade-off between inflation and unemployment is assumed to be dependent on government partisanship. Hence voters have different prior beliefs about Left and Right incumbents. The coding of government partisanship from Stone (2002) is based on press accounts, interviews for some countries, published sources, and the opinions of country experts. The score reflects the ideological position of the largest party in the government and ranges from -10 (extreme left on economic issues) to 10 (extreme right). The measure is well-suited to our analysis because it is based on pre-electoral rhetoric rather than policy. For instance, Poland from 1993-97 is coded as as having a Left government because of the SLD's populist electoral platform, rather than a moderate government, despite the fact that the SLD

did not reverse the key policies of the previous reformist coalitions. Similarly, there are significant differences in the scores of the Chernomyrdin, Kiriyenko, and Primakov governments in Russia, despite their similar economic policies. According to our argument, voters' priors about the government's type affect the way they perceive the government's actions. Hence, to avoid circularity, our measure should be based on perceived ideology, not on subsequent economic policy. For parliamentary systems, the partisanship of the prime minister's party is the partisanship of the government; for non-party coalitions and caretaker governments, the largest pro-government party determine's government partisanship. The coding scheme is more complicated for presidential systems. If the prime minister belongs to a parliamentary party, the partisanship score is based on that party's position. Otherwise, Stone (2002) uses "public statements by the president and prime minister at the time the government was appointed, public perceptions and expectations gleaned from the press and government reshufflings that increase or decrease the influence of ministers with known reformist or anti-reformist policy agendas." Because our hypothesis is conditional-the effect of breaking commitments on government duration depends on partisanship-we interact government partisanship with broken commitments. 


\section{Control Variables}

Drawing on the literature on government duration, ${ }^{5}$ which explains government tenure as a function of coalition and regime characteristics, we control for two measures of political fragmentation: the number of parties in the governing coalition and the seat share of the largest party in the governing coalition. Following the literature, we expect governments with a large number of coalition partners and governments lacking strong parliamentary support to be less stable. The quality of democracy should affect the cost of breaking public commitments, because it determines the ability of voters to punish governments for breaking promises. Our measure for democracy is taken from the Polity IV index. To investigate the effect of economic development, we include GDP per capita and annual economic growth. Przeworski et. al. (2000) find that income is an important prerequisite for political stability. Chiozza and Goemans (2004) also find that leaders of countries experiencing economic growth have longer tenure. We control for the executive powers of the president, as presidentialism is thought to contribute to government instability (Lijphart 1992, Linz 1997, Sartori 1997). ${ }^{6}$ On the other hand, the weaker political parties and divided governments typical of presidential systems disperse influence and reduce clarity of responsibility, thus undermining anti-incumbent voting (Powell and Whitten 1993, Powell 2000). Warwick (1994) finds that leaders become more likely to dissolve the government as elections approach, so we control for the number of months to the next parliamentary election. The shortened government duration could be due to worsening economic condition rather than to a loss of credibility: concurrent economic crisis could be the reason for voters' punishment, not devaluations. To control for this possibility, we include two proxies for economic crisis: a year of negative economic growth (Economic Crisis I) and the percentage rise in the Consumer Price Index over the last year (Economic Crisis II). ${ }^{7}$ 


\section{Estimation Method}

We use a parametric Weibull duration model, which allows us to recover the shape of the distribution of the time dependency, or the relationship between the likelihood that a leader will lose office and time. ${ }^{8}$ Diagnostic tests confirmed the results of earlier studies, which also found the Weibull model to predict the fall of governments better than alternative survival models. The Weibull model performs better (has a smaller Akaike Information Criterion) than the gamma, exponential, log-logistic, log-normal, and Gompertz. A similar result is reported in (Warwick 1994, Warwick and Easton 1992). Estimation of a Cox proportional hazards model produces results similar to those presented here. Estimation of the models with gamma frailty rejects the hypothesis that there is residual heterogeneity in the data.

\section{Results}

The estimation results are presented in Tables 2 and 3. The results are presented in accelerated time (ATF) parameterization of the Weibull model, so a positive coefficient indicates that an increase in the independent variable increases the expected government duration. The coefficient of the Breaking Commitments variable is negative and significant. Government Partisanship is negative and insignificant in all models; however, the interaction between the two is positive and significant in all models. Due to the inclusion of interaction terms and the resulting conditionality of estimates, the significance, sign, and magnitude of the effects of a variable of interest are not immediately indicated by its coefficient (Friedrich 1982). To aid in interpretation, in Table 3 we present first differences in expected Government Duration (in months) for all values of Government Partisanship, while changing the value of the break of commitment variable from 0 to 1 ). All other explanatory variables are held at their means, or at 0 for the dummy variables. ${ }^{9}$ 
[Table 2 about here.]

[Table 3 about here.]

As hypothesized, we find that the political costs of breaking exchange rate commitments are conditional on Government Partisanship: only Left governments' duration significantly decreases after breaking exchange rate commitments. In all models, Government Duration significantly decreases only for governments with Partisanship below -3 (See Figure 1). The effect of Breaking Commitments is insignificant for values of Partisanship higher than -3 for Models 1, 2, 4 and higher than -2 for Model 3. For Left governments, the effect is both statistically and substantively significant. For all models, the decrease in expected Government Duration ranges from -11 to -30 months for extreme left governments (Government Partisanship at -10) and from -1 to -21 (the average government duration is 16 months) for center-left governments (Government Partisanship at -3).

[Figure 1 about here.]

These results support the signaling explanation rather than the audience costs explanation of the relationship between exchange rate commitments and government collapse. If the political costs of breaking exchange rate commitments were automatic audience costs, we should observe similar decreases in government duration in the aftermath of realignments for Right governments. To the contrary, we observe that only Left-wing governments are punished for breaking their commitments, which is consistent with a model in which rational voters draw different inferences from similar behavior when they have different priors. This provides a rationale for why only left-leaning governments appear to be deterred from breaking their exchange rate commitments: only left-leaning governments are punished by rational voters for doing so.

These results are robust to the inclusion of numerous variables that have been shown to affect government duration in the existing literature. The economic development in- 
dicators (GDP Per Capita and GDP Annual Growth), as expected, have statistically significant effects that increase government duration. Political fragmentation indicators, the Number of Parties in the Governing Coalition and Parliamentary Support of the Largest Party in the Government have the expected signs (a greater number of parties decreases expected government duration while stronger parliamentary support increases it), but are not statistically significant. Interim governments have a negative sign, as expected, and the coefficient is significant. In each of the models estimated, we find a significant, negative effect of violating exchange rate commitments-talk about exchange rates is not cheap-but only when the government leans to the left. Right of center governments can say and do as they please; voters do not update their beliefs and do not vote them out of office when they abandon their exchange rate promises. The conditional effect of breaking exchange rate commitments is negative and significant for Left governments even after controlling for inflation or devaluation. Changing the cutoff point for breaks of commitments to one year does not change the substantive results (See Tables 4 and 5 in Appendix 2). Most importantly, our results are robust to the inclusion of standard proxies for economic crisis (see Model 4 in Table 2), which demonstrates that voters' punishments are motivated not only by worsening economic conditions per se, but also by the fact that governments have broken their promises.

\section{Case Studies}

We discuss two cases in order to illustrate the logic behind the results presented above. The cases were selected to highlight the two horns of the Left's dilemma: when exchange rate commitments are inconsistent with macroeconomic policies, Left governments are punished both for keeping their commitments and for breaking them. Still, the expected political costs from devaluations seem to be higher Both cases occurred in Slovakia, and both took place under the same leader, during two episodes in which Vladimir Meciar 
served as Prime Minister.

\section{The Dilemma of the Left: Take One}

The 1993 devaluation in Slovakia is a good example of the perils of exchange rate commitments for governments of the Left. Vladimir Meciar's government resisted devaluing, which it expected to be politically costly, but refused to rein in inflationary policies that ultimately made devaluation unavoidable. The overdue devaluation ultimately led to Meciar's resignation. The government's incoherent policy stance was widely criticized at home and abroad, and led to a mounting economic and political crisis of confidence. Finally driven to devalue the currency, Meciar sought to deflect criticism by blaming the policy on the Central Bank, a tactic that was not credible because the Central Bank was not independent. Meciar's party lost public support; he was forced to reshuffle his government, and the weakened coalition collapsed a few months later.

Prime Minister Meciar's government was mistrusted by Western diplomats and the market from the start. The government's leftist orientation had contributed to the split between Slovakia and the Czech Republic. A compromise had not been possible between Meciar, who promised a go-slow economic reform plan and the preservation of jobs in the poorer part of the country, and the Czech reformer Vaclav Klaus. In the background of this lack of credibility, cabinet members made contradictory statements about macroeconomic policy and devaluation in particular. In February 1993, the government's incoherent economic policy led to the collapse of talks between the government and the International Monetary Fund (IMF) for a 100 million dollar loan.

Economic uncertainty rapidly eroded the government's public support. Disagreements broke out within Meciar's party, several reform-minded ministers stepped down, and cabinet members joined the opposition in criticizing the government for failing to develop a clear economic strategy and refusing to implement reforms. The economic crisis deep- 
ened in the spring, and in April the opposition called for new elections. By May, after the defection of the foreign minister and several other deputies, Meciar's one-party government was left with only 66 seats in the 150-seat parliament. The successor to the former Communist Party, the Party of the Democratic Left, pressured Meciar to set up a broad coalition, thus implicitly threatening to force the minority government out of office. Meciar, however, was aware of the potential reputation costs from associating his party, already perceived as anti-reformist, with the ex-Communists. Meciar declined the offer, arguing that the United States would refuse to grant credits to Slovakia if such a coalition were formed. Coalition negotiations were initiated with the more reformist Slovak National Party.

Meanwhile, unemployment was rising and the pressure for devaluation was mounting, but cabinet members continued to speak against devaluation, recognizing its high political costs. Despite the government's public commitments to avoid devaluation, the central bank announced a 10.4 percent devaluation on July 9 to improve the price competitiveness of the country's exports. According to economic advisors to the government, the devaluation was carried out on the recommendation of the IMF (CTK, July 14, 1993). Meciar tried to distance himself from the decision, describing the devaluation as the "business of the bank," but this was not credible because the central bank was not independent. ${ }^{10}$ The devaluation led to only modest gains in export activity, contrary to expectations, and unemployment continued to rise. The economic recession increased public discontent, and the popularity of Meciar's HZDS (Movement for a Democratic Slovakia) dropped to 15 percent, from a high of 60 percent a year earlier. ${ }^{11}$ In October the Conservative Democratic Party called for early elections. In order to stave off pressure from opposition parties, Meciar's single party minority government entered into a coalition with the centrist Slovak National Party. The 14 parliamentary seats of the SNL gave Meciar's government a tenuous majority, but the government still lacked wide support. President Kovac and opposition leaders called for Meciar's resignation in De- 
cember. In March 1994, Meciar was ousted on a vote of no confidence and was replaced by Josef Moravcsik, heading a reformist government that excluded the HZDS.

For Meciar in 1993, the pegged exchange rate proved to be a political albatross. Afraid of the political consequences of reneging on his exchange rate commitment, he tolerated a dangerous inconsistency between exchange rate policy and monetary policy that drove the economy into crisis, eroded his public support, and ultimately brought down his coalition. When it finally occurred, devaluation further undermined his position-exactly as he had feared-because voters drew the inference that the Meciar government was too far to the left. Meciar's choice of coalition partners, namely his unwillingness to associate his government with the far Left, known for its inflationary policies, reflected his concern about voters' priors about Left parties.

\section{The Dilemma of the Left: Take Two}

Vladimir Meciar's second government refused to devalue in 1998, although devaluation was urgently called for, and was not punished as severely by voters as in 1993. Both the 1993 and 1998 changes in government are coded as government fall in our data set. Meciar's party emerged as the largest party in government after the 1998 elections, but it was forced to resign because it was unable to form a government. Under pressure from capital markets, and despite warnings that devaluation could not be long delayed, Meciar and other cabinet members claimed that devaluation was unnecessary and accused international financial institutions of supporting devaluation for political reasons. However, 1998 macroeconomic data indicate that devaluation was inevitable and might have been highly beneficial had it come earlier, as private-sector observers suggested at the time. The budget deficit had reached the projected sum for the year by the end of August 1998, and it continued to rise. The balance of payments deficits and internal debt reached new records. Noting the worsening economic fundamentals, both Moody's and Standard and 
Poor's rating agencies lowered Slovakia's debt ratings, and Standard and Poor's included Slovakia on a list of the seven countries with the most fragile financial systems in the world.

Meciar and his government resisted the idea of devaluation, making defense of the exchange rate a point of national pride. Bowing to government pressure, the central bank refused to devalue before the approaching parliamentary election in September. Meciar's constancy on the exchange rate may have helped to prevent a repeat of the punishment his party received in 1993, and his party emerged from the elections as the largest party in government, with 43 seats. This proved a hollow victory, however, because he did not command enough support to form a government, and was forced to resign in favor of a coalition of reform-minded parties. Again, the Left appeared to find itself in a no-win position: devaluation proclaims its leftist credentials, and the failure to devalue saddles it with a recession that is almost equally damaging.

Disappointed with the election results, Meciar warned voters of devaluation: "There will be hard times and devaluation, " he said, "but you have chosen this." Freed of Meciar's interference, the National Central Bank moved quickly to abrogate its exchange rate commitment in early October, while the coalition government was in the process of being formed. According to Central Bank officials, the decision was "the result of devaluation expectations by citizens and the corporate sphere, strengthened by the recent changes in the rating of Slovakia and also by the growing state budget deficit." In other words, the mistakes of the previous governments had made the decision unavoidable. Meciar's unwillingness to devalue, despite pressures from capital markets and financial institutions and the political damage caused by an overvalued exchange rate, illustrates the dilemma for the Left. Meciar must have recognized that the overvalued Crown was undermining his government, but he calculated that the political costs of devaluation prior to the election were even higher. 


\section{Conclusion}

Exchange rate commitments pose several linked puzzles. Why is it that governments and markets treat exchange rate commitments as important, when they are so often violated? Why is it that voters appear to punish governments that renege on these promises, in spite of the fact that maintaining exchange rate commitments when they are untenable is usually much more harmful?

We reject the conventional notion that voters punish politicians reflexively when they observe that a promise has been broken. Voters are sophisticated enough to draw inferences from government policies, and if they choose to vote against governments that break promises, there are probably rational calculations that lead them to believe that this strategy is their best response under the circumstances. In a model with rational voters, we find conditions under which it makes sense for voters to punish a government that breaks its promises-but only if their prior belief makes it rational to infer from the signal that the government is too far to the left. If the government is believed to lie to the right of the median voter, devaluation is more likely to indicate that devaluation is necessary than that the government is soft on inflation, so punishing devaluation is not optimal. We test the hypothesis that Left governments and only Left governments are punished when they renege on exchange rate commitments, and we find robust support for it.

This helps to explain prior findings that Left governments are particularly stubborn in their defense of exchange rate targets. Indeed, in our model, Left governments defend exchange rate targets under circumstances when Right governments that are more conservative would abandon them. The need to demonstrate their dedication to sound money, 
in fact, may drive Left governments to embrace politically disastrous economic policies, as Vladimir Meciar repeatedly demonstrated in Slovakia. 


\section{Appendix 1}

\section{Equilibrium Analysis}

The Incumbent's Choice of Exchange Rate Policy in the Second Period.

A Perfect Bayesian Equilibrium is found by backward induction. Since the equilibrium choice of exchange rate policy is a linear function of $\omega_{J}$ and $\epsilon_{I}$ :

$$
\pi_{J 1}=h_{L 1}+k_{\omega L 1} \omega_{J}+k_{\epsilon L 1} \epsilon_{1}
$$

observation of $\pi_{J 1}$ by voters does not enable them to disentangle the effect of $\omega_{J}$ from $\epsilon_{I}$. This implies that $k_{\omega L 1}=k_{\epsilon L 1}=k_{L 1}$. Therefore, (9) simplifies to:

$$
\pi_{J 1}=h_{L 1}+k_{L 1}\left(\omega_{J}+\epsilon_{I}\right)
$$

By the time the public forms its second-period beliefs about the government's type, it is engaged in a one-shot game with the government. As the government's policy choice in the second period does not affect voter's beliefs about the government's type, the government has a dominant strategy, which is $\pi_{L 2}=\omega_{L}$.

Aware of the government's dominant strategy in the second period, voters' set their policy expectations to the expected value (or posterior) of $\omega_{J}$ conditional on all available information. That is, $\pi_{J 2}^{e}=E\left(\omega_{J} \mid \pi_{J 1}\right)=\dot{\omega}_{J}$.

\section{The Voter's Decision to Re-elect}

Voters' preferences are single-peaked and the outcome of the election is determined by the preferred policy of the median voter. The party whose expected exchange rate policy in the second period is closest to the median voter's ideal point, $c_{m}$, wins. The incumbent party's expected policy is equivalent to the posterior of the voter's belief about the government's type $\omega_{J}$. Voters make an inference about the unknown value of $\omega_{L}$ from an

observation of $\pi_{L 1}=h_{L 1}+k_{L 1}\left(\omega_{L}+\epsilon_{1}\right)$. Using Theorem 2 from De Groot (1970, p.169), 
the posterior distribution of $\omega_{L}$ conditional on $\pi_{J 1}$ is:

$$
\dot{\omega}_{L}=\frac{p_{\omega}}{p_{\omega}+p_{\epsilon}} \mu_{\omega_{L}}+\frac{p_{\epsilon}}{p_{\omega}+p_{\epsilon}}\left(\frac{\pi_{L 1}-h_{L 1}}{k_{L 1}}\right)
$$

The utility of the median voter from re-electing the incumbent is $-\left(\dot{\omega}_{L}-c_{m}\right)^{2}$ and the utility from electing the challenger is: $-\left(\omega_{R}-c_{m}\right)^{2}$. The median voter will re-elect the incumbent only if the expected utility of this action is higher than the expected utility from electing the challenger. The decision rule of the median voter implies that there exists a critical value $c_{m}^{c}$ such that if $c_{m} \leq c_{m}^{c}$, the Right-wing challenger wins the election, and if $c_{m}>c_{m}^{c}$, the Left incumbent is re-elected. Without loss of generality, if the incumbent is Left, the value of $c_{m}^{c}$ is obtained from:

$$
-\left(\dot{\omega}_{L}-c_{m}^{c}\right)^{2}=-\left(\omega_{R}-c_{m}^{c}\right)^{2}
$$

Assumption 1: We assume that $\omega_{L}>\omega_{R}$, i.e. while the public updates its beliefs about the incumbent's type, $\mathrm{L}$ is always perceived to be the left party (see Canavan and Tommasi 1997). In terms of exchange rate policy, this means that the expected rate of devaluation by the Left is bigger than (to the right of) that of the Right. Simplifying, we obtain:

$$
c_{m}^{c}=\frac{\dot{\omega}_{L}+\omega_{R}}{2}
$$

Because $c_{m}$ is uniformly distributed, the probability that the Left government is reelected, which is equivalent to the probability that $c_{m}$ is to the right of $c_{m}^{c},{ }^{12}$ is given by:

$$
P^{L}\left(\pi_{J I}\right)=\frac{\bar{c}-c_{m}^{c}}{\bar{c}-\underline{c}}
$$

The Left Incumbent's Choice of Exchange Rate Policy in the First Period. Substituting the expressions for $\pi_{J 2}$ and $P^{L}\left(\pi_{J I}\right)$ into (1), we obtain the following first- 
and second-order conditions for the maximization problem of a Left incumbent:

$$
\begin{gathered}
-2 \pi_{L 1}+2\left(\omega_{L}+\epsilon_{1}\right)-\delta \frac{p_{\epsilon}}{2 h_{L 1}\left(p_{\omega}+p_{\epsilon}\right)(\bar{c}-\underline{c})}(b+l)=0 \\
-2<0
\end{gathered}
$$

Rearranging the first-order condition, we obtain the following equilibrium rate of devaluation:

$$
\pi_{L 1}=\omega_{L}+\epsilon_{1}-\delta \frac{p_{\epsilon}}{4 h_{L 1}\left(p_{\omega}+p_{\epsilon}\right)(\bar{c}-\underline{c})}(b+l)
$$

Equation (16) implies that $h_{L 1}=1$ and $k_{L 1}=-\delta \frac{p_{\epsilon}}{4\left(p_{\omega}+p_{\epsilon}\right)(\bar{c}-\underline{c})}(b+l)$.

A similar derivation shows that the equilibrium rate of devaluation for a Right incumbent is:

$$
\pi_{R 1}=\omega_{R}+\epsilon_{1}+\delta \frac{p_{\epsilon}}{4 h_{R 1}\left(p_{\omega}+p_{\epsilon}\right)(\bar{c}-\underline{c})}(b+l)
$$

This implies that $h_{R 1}=1$ and $k_{R 1}=\delta \frac{p_{\epsilon}}{4\left(p_{\omega}+p_{\epsilon}\right)(\bar{c}-\underline{c})}(b+l)$ 


\section{Notes}

${ }^{1}$ The assumption of normality implies that some values of devaluation and the government's type are negative. We think of the normal distribution as an approximation to a distribution over the positive real line and truncated at zero, an approximation relatively accurate if $\mu_{\omega_{J}}$ is a large positive number and the probability that $\omega_{J}$ is negative is small (see Canavan and Tommasi 1997).

${ }^{2}$ In the few cases when the prime minister dies unexpectedly, the government is coded as continuing.

${ }^{3}$ Membership in the European Union requires a preliminary two-year participation in the Exchange Rate Mechanism, where the exchange rate is set to be fixed, even though oscillation band is allowed on each side.

${ }^{4}$ We do not include in the sample countries that had currency board regimes, namely, Bulgaria, Estonia, and Lithuania. Because currency boards entail special reserve requirements and often, monetary assistance from another country, we believe they should be analyzed separately (see Bodea 2008).

${ }^{5}$ For a review, see Laver and Schofield 1999 and Warwick 1994.

${ }^{6}$ The measure for presidential powers is based on a modification of the Hellman-Tucker score, modified to reflect coding disagreements and updated from 1996-99 to reflect constitutional and extraconstitutional changes that took place after the original data were gathered. The coding scheme generally follows the one created by Matthew Shugart and John Carey (1992) but was modified by Joel Hellman and Joshua Tucker.

${ }^{7}$ We also replicate the results using different time cut-off points, namely, 6 months and 2 years.

${ }^{8}$ The ability to recover the shape of the distribution describing the time dependence of the risk of failure is obtained at the expense of making a monotonicity assumption about the time dependence of the risk of failure.

${ }^{9}$ Expected government duration for substantively interesting values of the explanatory variables is computed with Clarify (King et.al.)

${ }^{10}$ Excerpts from the premier's Sunday's address, BBC Monitoring Service; Central Europe and the Balkans, July 15, 1993.

${ }^{11}$ Reuters, October 7, 1993

${ }^{12}$ Again, the traditional directions are reversed because we are talking about exchange rate policy and the Left is associated with higher devaluation (to the right of that of the Left in terms of magnitude.) 


\section{Appendix 2}

[Table 4 about here.]

[Table 5 about here.]

[Table 6 about here.]

[Table 7 about here.] 
[Table 8 about here.] 


\section{References}

Adam Przeworski, Michael Alvarez, Jose Antonio Cheibub and Fernando Limongi. 2000. Democracy and Development; Political institutions and Well-Being in the World 19501990. Cambridge: Cambridge University Press.

Alesina, A. and Tabellini G. 1995. "A Positive Theory of Fiscal Deficits and Government Debt in a Democracy." Review of Economic Studies 59(2):663-88.

Alesina, Alberto and N. Roubini. 1992. "Political Cycles in the Macroeconomy." Review of Economic Studies 59:403-14.

Alvarez, Michael, Geoffrey Garett and Peter Lange. 1985. "Government Partisanship, Labor Organization, and Macroeconomic Performance." American Political Science Review 85(2):539-56.

Backus, David and John Driffil. 1985. "Inflation and Reputation." American Economic Review 75(3):550-38.

Barro, Robert and David Gordon. 1983. "A Positive Theory of Monetary Policy in a Natural Rate Model." The Journal of Political Economy 91(4):589-610.

Bernhard, William and David Leblang. 1999. "Democratic Institutions and Exchange Rate Commitments." International Organization 53(1):71-97.

Bernhard, William and David Leblang. 2002. "Political Parties and Monetary Commitments." International Organization 56(4):71-97.

Bodea, Cristina. 2008. "The Political Economy of Fixed Excahnge Rate Regimes: The Experience of Post-Communist Countries." European Journal of Political Economy Forthcoming.

Bosco, Luigi. 1987. "Determinants of the Exchange Rate Regimes in LDC's: Some Empirical Evidence." Economic Notes 1:119-43. 
Canavan, Chris and Mariano Tommasi. 1997. "On the Credibility of Alternative Exchange Rate Regimes." Journal of Development Economics 54(1):101-122.

Chiozza, Giakomo and Hein Gohmans. 2004. "Avoiding Diversionary Tragets." Journal of Peace Research 41(4):423-443.

Cooper, Richard. 1971. Currency Devaluations in Developing Countries. Princeton University.

Cooper, Richard. 2002. Macroeconomic Policies of Developed Democracies. Cambridge: Cambridge University Press.

Cukierman, Alex and Mariano Tommasi. 1998. "When Does it Take a Nixon to Go to China?" The American Economic Review 88(1):180-197.

Drazen, Allen and Paul Masson. 1994. "Credibility of Policies Versus Credibility of Policy-Makers." The Quarterly Journal of Economics 109(3):735-754.

Dreyer, Jacob. 1992. The Economics of Monetary Integration. Cambridge: Cambridge University Press.

Edwards, Sebastian. 1989. Real Exchange Rates, Devaluation, and Adjustment: Exchange Rate Policy in Developing Countries. Cambridge: MIT UNiversity Press.

Edwards, Sebastian and Peter Montiel. 1989. "Devaluation Crises and Macroeconomic Consequences of Postponed Adjustment in Developing Countries." IMF Staff Papers 36.

Eichengreen, Barry, Andrew Rose and Charles Wyplozs. 1996. "Contagious Currency Crises." CEPR Discussion Paper 1453.

Fearon, James. 1994. "Domestic Political Audiences and the Escalation of international Disputes." American Poltiical Science Review 88(3):577-92.

Flood, R. and P. Isaard. 1989. "Monetary Policy Strategies." IMF Staff Papers 36:612-32. 
Frankel, Jeffrey. 2005. "Contractionary Currency Crises in Developing Countries." IMF Staff Papers .

Frankel, Jeffrey and Andrew Rose. 1996. "Currency Crashes in Emerging Markets: An Empirical Treatment." Journal of International Economics 41(3-4):451-366.

Friedrich, Robert. 1982. "In Defense of Multiplicative Terms in Multiple Regression Equations." American Journal of Poltiical Science 26:797-833.

Garrett, Geoffrey. 1995. "Capital Mobility, Trade, and the Domestic Politics of Economic Policy." International Organization 49(4):657-88.

Garrett, Geoffrey and Peter Lange. 1995. "Internationalization, Institutions, and Political Change." International Organization 49(4):627-56.

Giavazzi, Francesco and Marco Pagano. 1998. "The Advantage of Tying One's Hands: EMS Discipline and Central Bank Credibility." European Economic Review 32(5):10551082.

Hibbs, Douglas. 1977. "Political Parties and Macroeconomic Policy." The American Political Science Review 71:1467-87.

Iversen, Torben. 1999. Contested Economic Institutions: The Politics of Macroeconomics and Wage Bargaining in Advanced Democracies. Cambridge: Cambridge University Press.

Kaminski, Graciela, Saul Lizondo and Carmen Reinhart. 1998. "Leading Indicators of Currency Crises." IMF Staff Papers 45(1).

Klein, M. and N. Marion. 1994. "Explaining the Duration of Exchange Rate Pegs." NBER Working Paper No. 46511.

Krugman, Paul. 1979. "A Model of Balance of Payments Crisis." Journal of Monetary Credit and Banking 11(3):311-325. 
Kydland, Finn and Edward Prescott. 1977. "Rules Rather Than Discretion: The Inconsistency of Optimal Plans." Journal of Political Economy 85(3):473-91.

Laver, Michael and Norman Schofield. 1999. Multi-party Government: The Politics of Coalition in Europe. New York: Oxford University Press.

Leblang, David. 2005. "Pegs and Politics." Working Paper .

Lijphart, Arend. 1992. Parliamentary versus Presidential Government. Oxford and New York: Oxford University Press.

Linz, Juan. 1997. Some Thoughts on Presidentialism in Post-Communist Europe. In Post-Communist Presidents, ed. Ray Taras. Cambridge: Cambridge University Press.

Lohmann, Susanne. 1990. "Monetary Policy Strategies: A Correction." IMF Staff Papers

Markowski, Radoslaw. 2006b. "The Polish Elections of 2005." West European Politics $29(4): 814-832$.

Markowski:2006a. 2006a. "The 2007 Polish Parliamentary Election: Some Structuring, Still a Lot of Chaos." West European Politics 29(1):37-41.

Milesi-Feretti, Gian Maria. 1995. "The Disadvantage of Tying Their Hands: On the Political Economy of Policy Commitments." Economic Journal 105:1381-1402.

Oatley, Thomas. 1999. "How Constraining is Capital Mobility? The Partisan Hypothesis in an Open Economy." American Journal of Political Science 43(4):1003-27.

Obstfeld, Maurice and Kenneth Rogoff. 1995. "Exchange Rate Dynamics Redux." Journal of Political Economy 103(3):624-660.

Persson, T. and L. Svensson. 1989. "Why a Stubborn Conservative Might Run a Deficit: Polticy with Time-Inconsistent Preferences." Quarterly Journal of Economics 104:32545. 
Powell, Bingham, Jr. 2000. Elections as Instruments of Democracy: Proportional and Majoritarian Visions. New Haven: Yale University Press.

Powell, Bingham Jr. and Guy Whiten. 1993. "A Cross-National Analysis of Ecoenomic Voting: Taking Account of the Political Context." American Journal of Political Science $37(2): 391-414$.

Ramsay, Kristopher. 2004. "Politics at the Water's Edge." Journal of Conflict Resolution 48(4):459-486.

Rogoff, Kenneth. 1985. "The Optimal Degree of Commitment to an Intermediate Monetary Target." Quarterly Journal of Economics 100(4):1169-1190.

Sartori, Giovanni. 1997. Comparative Constitutional Engineering: An Inquiry into Structures, Incentives, and Outcomes, 2nd Edition. New York: New York University Press.

Savvides, Andreas. 1990. "Real Exchange Rate Volatility and the Choice of Exchange Rate Regime by Developping Countries." Journal of Money and Finance 9(4):440-54.

Simmons, Beth. 1994. Democracy and Development: Political Institutions and Well-Being in the World. Princeton: Princeton University Press.

Stone, Randall. 2002. Lending Credibility: The International Monetary Fund and the Post-Communist Transition. Princeton University Press.

Szolt, Enyedi. 2006. Party Politics in Post-Communist Transition. In Handbook of Political Parties, ed. William Crotty and Richard Katz. London: Sage pp. 228-238.

Walker, Robert. 2009. "Political Instability and Exchange Rate Regimes: The Intervening Role of Domestic Political Institutions." Working Paper.

Warwick, Paul. 1994. Government Survival in parliamentary Democracies. New York: Cambridge University Press. 
Warwick, Paul and Stephen Easton. 1992. "Cabinet Stability Controversy: New Perspectives on a Classic Problem." American Journal of Political Science 30(1):122-46.

Wickham, Peter. 1985. "The Choice of Exchange Rate Regime in Developping Countries." IMF Staff Papers 32(2):248-88. 


\section{List of Figures}

1 Change in expected government duration when a commitment is broken . . . . . . . 40 


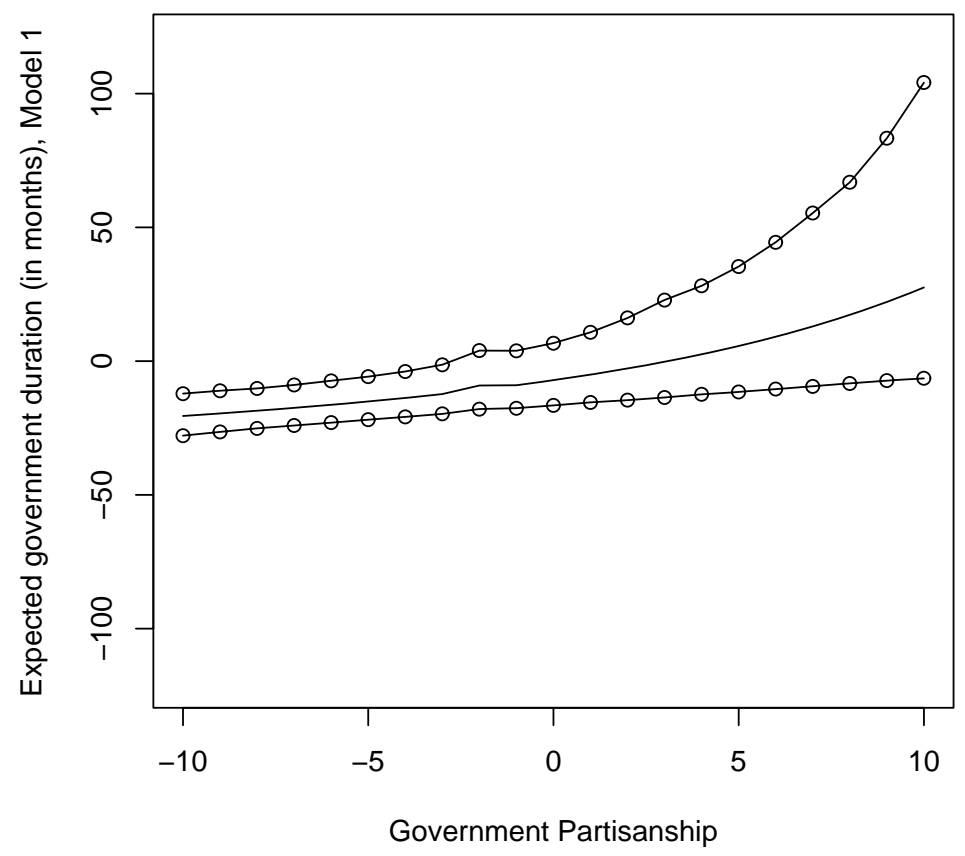

Figure 1: Change in expected government duration when a commitment is broken 


\section{List of Tables}

1 Exchange Rate Commitments, Partisanship, and Government Fall in the Communist Europe . . . . . . . . . . . . . . . . . . . . . . . . 42

2 Breaking Exchange Rate Commitments and Government Fall . . . . . . .

3 Effect of Breaking Exchange Rate Commitments on Government Duration (Number of Months), First Differences . . . . . . . . . . . . . . . . . . 44

4 Breaking Exchange Rate Commitments and Government Fall . . . . . . .

5 Effect of Breaking Exchange Rate Commitments on Government Duration (Number of Months), First Differences . . . . . . . . . . . . . . . . . 46

6 Breaking Exchange Rate Commitments (excluding fixed exchange rates) and Government Fall . . . . . . . . . . . . . . . . . . . . . . . . . . 47

7 Effect of Breaking Exchange Rate Commitments on Government Duration (Number of Months), First Differences . . . . . . . . . . . . . . . . . . 48

8 Summary Statistics . . . . . . . . . . . . . . . . . . 49 
Table 1: Exchange Rate Commitments, Partisanship, and Government Fall in the Communist Europe

\begin{tabular}{lcc}
\hline \hline & Left & Right \\
\hline \hline Government Partisanship & 95 & 97 \\
Exchange Rate Commitments & 13 & 22 \\
Broken Commitments & 16 & 36 \\
Collapse After Broken Commitments & 6 & 5 \\
\hline
\end{tabular}


Table 2: Breaking Exchange Rate Commitments and Government Fall

\begin{tabular}{|c|c|c|c|c|}
\hline & Model 1 & Model 2 & Model 3 & Model 4 \\
\hline Break of Exchange Rate Commitment & $\begin{array}{c}-0.948^{* * 13} \\
(0.509)\end{array}$ & $\begin{array}{c}-1.089^{* *} \\
(0.523)\end{array}$ & $\begin{array}{c}-1.051^{* *} \\
(0.498)\end{array}$ & $\begin{array}{c}-0.967^{* *} \\
(0.419)\end{array}$ \\
\hline Government Partisanship & $\begin{array}{c}-0.011 \\
(0.009)\end{array}$ & $\begin{array}{c}-0.011 \\
(0.009)\end{array}$ & $\begin{array}{l}-0.011 \\
(0.009)\end{array}$ & $\begin{array}{c}-0.01 \\
(0.01)\end{array}$ \\
\hline Break of Exchange Rate Commitment*Partisanship & $\begin{array}{c}0.11^{* * *} \\
(0.034)\end{array}$ & $\begin{array}{c}0.11^{* * *} \\
(0.033)\end{array}$ & $\begin{array}{c}0.11^{* * *} \\
(0.032)\end{array}$ & $\begin{array}{l}0.106^{* *} \\
(0.036)\end{array}$ \\
\hline Break of Exchange Rate Commitment*Democracy & $\begin{array}{c}0.182^{* *} \\
(0.066)\end{array}$ & $\begin{array}{c}0.194^{* * *} \\
(0.068)\end{array}$ & $\begin{array}{c}0.187^{* *} \\
(0.064)\end{array}$ & $\begin{array}{l}0.171^{* *} \\
(0.062)\end{array}$ \\
\hline Democracy & $\begin{array}{l}-0.025 \\
(0.017)\end{array}$ & $\begin{array}{l}-0.027 \\
(0.017)\end{array}$ & $\begin{array}{l}-0.028 \\
(0.017)\end{array}$ & $\begin{array}{c}-0.026 \\
(0.017)\end{array}$ \\
\hline Months to Elections & $\begin{array}{c}-0.017^{* * *} \\
(0.004)\end{array}$ & $\begin{array}{c}-0.017^{* * *} \\
(0.004)\end{array}$ & $\begin{array}{c}-0.016^{* * *} \\
(0.004)\end{array}$ & $\begin{array}{c}-0.016^{* * *} \\
(0.004)\end{array}$ \\
\hline Number of Coalition Members & $\begin{array}{l}-0.073 \\
(0.048)\end{array}$ & $\begin{array}{l}-0.067 \\
(0.048)\end{array}$ & $\begin{array}{l}-0.074 \\
(0.048)\end{array}$ & $\begin{array}{l}-0.074^{*} \\
(0.041)\end{array}$ \\
\hline Parliamentary Support & $\begin{array}{c}0.288 \\
(0.381)\end{array}$ & $\begin{array}{c}0.386 \\
(0.384)\end{array}$ & $\begin{array}{c}0.373 \\
(0.361)\end{array}$ & $\begin{array}{c}0.379 \\
(0.326)\end{array}$ \\
\hline Executive Powers Score & $\begin{array}{l}-0.002 \\
(0.017)\end{array}$ & $\begin{array}{c}0.008 \\
(0.017)\end{array}$ & $\begin{array}{c}0.003 \\
(0.018)\end{array}$ & $\begin{array}{c}0.005 \\
(0.017)\end{array}$ \\
\hline Interim Government & $\begin{array}{c}-0.888^{* * *} \\
(0.168)\end{array}$ & $\begin{array}{c}-0.84^{* * *} \\
(0.161)\end{array}$ & $\begin{array}{c}-0.749^{* * *} \\
(0.153)\end{array}$ & $\begin{array}{c}-0.737^{* * *} \\
(0.187)\end{array}$ \\
\hline War & $\begin{array}{c}-0.459^{*} \\
(0.253)\end{array}$ & $\begin{array}{l}-0.398 \\
(0.257)\end{array}$ & $\begin{array}{l}-0.183 \\
(0.271)\end{array}$ & $\begin{array}{c}-0.17 \\
(0.256)\end{array}$ \\
\hline Log(GDP Per Capita) & & $\begin{array}{c}0.131^{*} \\
(0.07)\end{array}$ & $\begin{array}{l}0.107 \\
(0.07)\end{array}$ & $\begin{array}{c}0.256 \\
(0.078)\end{array}$ \\
\hline GDP Growth & & & $\begin{array}{c}0.013^{* *} \\
(0.005)\end{array}$ & $\begin{array}{c}0.015^{* * *} \\
(0.01)\end{array}$ \\
\hline Economic Crisis I & & & & $\begin{array}{c}0.178 \\
(0.154)\end{array}$ \\
\hline Economic Crisis II & & & & $\begin{array}{c}-0.001 \\
(0.001)\end{array}$ \\
\hline Constant & $\begin{array}{c}3.859^{* * *} \\
(0.364)\end{array}$ & $\begin{array}{c}2.753^{* * *} \\
(0.703)\end{array}$ & $\begin{array}{c}2.978^{* * *} \\
(0.723)\end{array}$ & $\begin{array}{c}2.834^{* * *} \\
(0.729)\end{array}$ \\
\hline Observations & 2355 & 2355 & 2355 & 2355 \\
\hline Shape Parameter & 1.571 & 1.604 & 1.655 & 1.658 \\
\hline $95 \%$ Confidence Interval & $(1.373-1.798)$ & $(1.396-1.844)$ & $(1.436-1.908)$ & $(1.469-1.869)$ \\
\hline Wald Chi-square & 161.68 & 174.15 & 193.42 & 206.35 \\
\hline Log Likelihood & -128.83 & -127.447 & -125.418 & -124.452 \\
\hline
\end{tabular}


Table 3: Effect of Breaking Exchange Rate Commitments on Government Duration (Number of Months), First Differences

\begin{tabular}{|c|c|c|c|c|c|c|c|}
\hline Partisanship $^{14}$ & -10 & -7 & -3 & 0 & 3 & 7 & 10 \\
\hline Model 1 & $\begin{array}{l}-21 * * * 15 \\
(-28,-12)\end{array}$ & $\begin{array}{c}-19 * * * \\
(-25,-10)\end{array}$ & $\begin{array}{c}-18^{* *} \\
(-20,-1)\end{array}$ & $\begin{array}{c}-10 \\
(-17,7)\end{array}$ & $(-14,23)$ & $\begin{array}{c}-0.2 \\
(-9,55)\end{array}$ & $\begin{array}{c}28 \\
(-6,104)\end{array}$ \\
\hline Model 2 & $\begin{array}{c}-21 * * * \\
(-28,-13)\end{array}$ & $\begin{array}{c}-18 * * * \\
(-25,-10)\end{array}$ & $\begin{array}{l}-13 * * * \\
(-20,-3)\end{array}$ & $\begin{array}{c}-9 \\
(-18,5)\end{array}$ & $\begin{array}{c}-2 \\
(-15,19)\end{array}$ & $\begin{array}{c}10 \\
(-12,50)\end{array}$ & $\begin{array}{c}23 \\
(-10,87)\end{array}$ \\
\hline Model 3 & $\begin{array}{c}-21 * * * \\
(-30,-11)\end{array}$ & $\begin{array}{c}-18^{* * *} \\
(-24,-11)\end{array}$ & $\begin{array}{l}-13 * * * \\
(-21,-2)\end{array}$ & $\begin{array}{c}-9 \\
(-17,2)\end{array}$ & $(-14,14)$ & $\begin{array}{c}9 \\
(-11,42)\end{array}$ & $\begin{array}{c}22 \\
(-8,81)\end{array}$ \\
\hline Model 4 & $\begin{array}{c}-18 * * * \\
(-23,-13)\end{array}$ & $\begin{array}{c}-18^{* * *} \\
(-24,-10)\end{array}$ & $\begin{array}{c}-13^{* * *} * \\
(-19,-5)\end{array}$ & $\begin{array}{c}-8 \\
(-16,2)\end{array}$ & $(-13,15)$ & $\begin{array}{c}10 \\
(-8,45)\end{array}$ & $\begin{array}{c}23 \\
(-6,85)\end{array}$ \\
\hline
\end{tabular}


Table 4: Breaking Exchange Rate Commitments and Government Fall

\begin{tabular}{|c|c|c|c|c|c|}
\hline & Model 5 & Model 6 & Model 7 & Model 8 & Model 9 \\
\hline Break of Exchange Rate Commitment (last 6 months) & $\begin{array}{c}-0.959 * 16 \\
(0.533)\end{array}$ & $\begin{array}{c}-2.204^{* * *} \\
(0.693)\end{array}$ & $\begin{array}{c}-1.059^{* *} \\
(0.053)\end{array}$ & $\begin{array}{c}-2.141 * * \\
(0.864)\end{array}$ & \\
\hline Break of Exchange Rate Commitment (last 12 months) & $\begin{array}{c}-0.959^{*} \\
(0.533)\end{array}$ & $\begin{array}{c}-2.204^{* * * *} \\
(0.693)\end{array}$ & $\begin{array}{c}-1.059^{* *} \\
(0.053)\end{array}$ & $\begin{array}{c}-2.141^{* *} \\
(0.864)\end{array}$ & $\begin{array}{c}-0.979^{* *} \\
(0.467)\end{array}$ \\
\hline Government Partisanship & $\begin{array}{c}0.004 \\
(0.009)\end{array}$ & $\begin{array}{l}-0.013 \\
(0.012)\end{array}$ & $\begin{array}{l}-0.003 \\
(0.011)\end{array}$ & $\begin{array}{l}-0.015 \\
(0.096)\end{array}$ & $\begin{array}{l}-0.012 \\
(0.009)\end{array}$ \\
\hline Break of Exchange Rate Commitment*Partisanship & $\begin{array}{c}0.092^{* *} \\
(0.032)\end{array}$ & $\begin{array}{c}0.108^{* *} \\
(0.035)\end{array}$ & $\begin{array}{c}0.092^{* * *} \\
(0.031)\end{array}$ & $\begin{array}{c}0.108 * * * \\
(0.028)\end{array}$ & $\begin{array}{c}0.085^{* *} \\
(0.042)\end{array}$ \\
\hline Break of Exchange Rate Commitment*Democracy & $\begin{array}{c}0.171 * * * \\
(0.068)\end{array}$ & $\begin{array}{c}0.337 * * * \\
(0.099)\end{array}$ & $\begin{array}{c}0.180^{* *} \\
(0.069)\end{array}$ & $\begin{array}{c}0.328^{* *} \\
(0.123)\end{array}$ & $\begin{array}{c}0.131 \\
(0.178)\end{array}$ \\
\hline Democracy & $\begin{array}{l}-0.015 \\
(0.018)\end{array}$ & $\begin{array}{c}-0.033^{*} \\
(0.018)\end{array}$ & $\begin{array}{l}-0.008 \\
(0.017)\end{array}$ & $\begin{array}{l}-0.029^{*} \\
(0.017)\end{array}$ & $\begin{array}{l}-0.032^{*} \\
(0.017)\end{array}$ \\
\hline Months to Elections & $\begin{array}{c}-0.016^{* * *} \\
(0.004)\end{array}$ & $\begin{array}{c}-0.015 * * \\
(0.005)\end{array}$ & $\begin{array}{c}-0.0154^{* * *} \\
(0.005)\end{array}$ & $\begin{array}{c}-0.015^{* * *} \\
(0.004)\end{array}$ & $\begin{array}{c}-0.014 * * * \\
(0.004)\end{array}$ \\
\hline Number of Coalition Members & $\begin{array}{l}-0.065 \\
(0.049)\end{array}$ & $\begin{array}{c}-0.094 * * \\
(0.047)\end{array}$ & $\begin{array}{l}-0.061 \\
(0.052)\end{array}$ & $\begin{array}{c}-0.094 * * \\
(0.046)\end{array}$ & $\begin{array}{c}-0.104^{* *} \\
(0.043)\end{array}$ \\
\hline Parliamentary Support & $\begin{array}{c}0.417 \\
(0.412)\end{array}$ & $\begin{array}{c}0.176 \\
(0.441)\end{array}$ & $\begin{array}{c}0.423 \\
(0.429)\end{array}$ & $\begin{array}{c}0.181 \\
(0.388)\end{array}$ & $\begin{array}{c}0.295 \\
(0.352)\end{array}$ \\
\hline Executive Powers Score & $\begin{array}{c}0.004 \\
(0.018)\end{array}$ & $\begin{array}{c}0.002 \\
(0.016)\end{array}$ & $\begin{array}{c}0.006 \\
(0.018)\end{array}$ & $\begin{array}{c}0.003 \\
(0.017)\end{array}$ & $\begin{array}{c}0.002 \\
(0.017)\end{array}$ \\
\hline Interim Government & $\begin{array}{c}-0.585^{* *} \\
(0.184)\end{array}$ & $\begin{array}{c}-0.641^{* *} \\
(0.208)\end{array}$ & $\begin{array}{c}-0.489^{* *} \\
(0.213)\end{array}$ & $\begin{array}{c}-0.632^{* * *} \\
(0.169)\end{array}$ & $\begin{array}{c}-0.733^{* * *} \\
(0.155)\end{array}$ \\
\hline War & $\begin{array}{l}-0.294 \\
(0.354)\end{array}$ & $\begin{array}{c}-0.448^{* *} \\
(0.216)\end{array}$ & $\begin{array}{l}-0.301 \\
(0.376)\end{array}$ & $\begin{array}{c}-0.466^{* *} \\
(0.233)\end{array}$ & $\begin{array}{l}-0.226 \\
(0.257)\end{array}$ \\
\hline Log(GDP Per Capita) & $\begin{array}{c}0.149^{* *} \\
(0.075)\end{array}$ & $\begin{array}{c}0.109 \\
(0.093)\end{array}$ & $\begin{array}{c}0.131 \\
(0.081)\end{array}$ & $\begin{array}{c}0.104 \\
(0.068)\end{array}$ & $\begin{array}{c}0.083 \\
(0.068)\end{array}$ \\
\hline GDP Growth & $\begin{array}{l}0.013^{*} \\
(0.007)\end{array}$ & $\begin{array}{c}0.015^{* *} \\
(0.007)\end{array}$ & $\begin{array}{c}0.001 \\
(0.008)\end{array}$ & $\begin{array}{c}0.015^{* *} \\
(0.006)\end{array}$ & $\begin{array}{c}0.012^{* *} \\
(0.005)\end{array}$ \\
\hline Devaluation & & $\begin{array}{c}0.001 \\
(0.001)\end{array}$ & & $\begin{array}{c}0.005 \\
(0.004)\end{array}$ & \\
\hline Inflation & $\begin{array}{c}0.001 \\
(0.001)\end{array}$ & & $\begin{array}{c}0.003 \\
(0.011)\end{array}$ & & \\
\hline Devaluation*Democracy & & & & $\begin{array}{c}0 \\
(0.001)\end{array}$ & \\
\hline Inflation*Democracy & & & $\begin{array}{c}-0.001 \\
(0.002)\end{array}$ & & \\
\hline Devaluation*Partisanship & & & & $\begin{array}{c}0 \\
(0.001)\end{array}$ & \\
\hline Inflation*Partisanship & & & $\begin{array}{c}0.001 \\
(0.001)\end{array}$ & & \\
\hline Constant & $\begin{array}{c}2.493^{* * *} * \\
(0.802)\end{array}$ & $\begin{array}{c}3.147^{* * *} \\
(0.889)\end{array}$ & $\begin{array}{c}2.569^{* * *} \\
(0.858)\end{array}$ & $\begin{array}{c}3.16^{* * *} * \\
(0.687)\end{array}$ & $\begin{array}{c}3.215^{* * *} \\
(0.668)\end{array}$ \\
\hline Observations & 1863 & 2077 & 1863 & 2077 & 2335 \\
\hline Shape Parameter & 1.716 & 1.701 & 1.7126 & 1.7033 & 1.679 \\
\hline $95 \%$ Confidence Interval & $(1.469-2.004)$ & $(1.503,1.924)$ & $(1.468-1.999)$ & $(1.461-1.986)$ & $(1.457-1.935)$ \\
\hline Wald Chi-square & 137.65 & 142.78 & 134.70 & 186.03 & 190.99 \\
\hline Log Likelihood & -98.141 & -103.122 & -96.7775 & -102.654 & -124.549 \\
\hline
\end{tabular}


Table 5: Effect of Breaking Exchange Rate Commitments on Government Duration (Number of Months), First Differences

\begin{tabular}{|c|c|c|c|c|c|c|c|}
\hline Partisanship $^{17}$ & -10 & -7 & -3 & 0 & 3 & 7 & 10 \\
\hline Model 5 & $\begin{array}{c}-15.16^{* * * 18} \\
(-21,-8)^{19}\end{array}$ & $\begin{array}{c}-14^{* * *} \\
(-20,-6)\end{array}$ & $\begin{array}{c}-11^{* *} \\
(-17,-1)\end{array}$ & $\begin{array}{c}-7 \\
(-15,5)\end{array}$ & $\begin{array}{c}-2 \\
(-14,15)\end{array}$ & $\begin{array}{c}7 \\
(-12,42)\end{array}$ & $\begin{array}{c}18 \\
(-11,74)\end{array}$ \\
\hline Model 6 & $\begin{array}{c}-24 * * * \\
(-32,-16)\end{array}$ & $\begin{array}{c}-22^{* * *} \\
(-29,-14)\end{array}$ & $\begin{array}{l}-19^{* * *} \\
(-25,-8)\end{array}$ & $\begin{array}{c}-15^{* *} \\
(-23,-2)\end{array}$ & $\begin{array}{c}-12 \\
(-21,7)\end{array}$ & $\begin{array}{c}-5 \\
(-18,24)\end{array}$ & $\begin{array}{c}2 \\
(-17,48)\end{array}$ \\
\hline Model 7 & $\begin{array}{c}-15.44^{* * *} \\
(-21,-9)\end{array}$ & $\begin{array}{c}-14 * * * \\
(-19,-7)\end{array}$ & $\begin{array}{l}-11^{* * *} \\
(-17,-3)\end{array}$ & $\begin{array}{c}-8 \\
(16,3)\end{array}$ & $\begin{array}{c}-4 \\
(-14,13)\end{array}$ & $\begin{array}{c}5 \\
(-13,39)\end{array}$ & $\begin{array}{c}15 \\
(-11,72)\end{array}$ \\
\hline Model 8 & $\begin{array}{c}-23^{* * *} \\
(-30,-16)\end{array}$ & $\begin{array}{c}-21 * * * \\
(-23,-14)\end{array}$ & $\begin{array}{l}-18^{* * *} \\
(-24,-9)\end{array}$ & $\begin{array}{c}-15^{* *} \\
(-22,-3)\end{array}$ & $\begin{array}{c}-11 \\
(-20,6)\end{array}$ & $\begin{array}{c}-4 \\
(-18,25)\end{array}$ & $\begin{array}{c}3 \\
(-17,44)\end{array}$ \\
\hline Model 9 & $\begin{array}{c}-21 * * * \\
(-27,-12)\end{array}$ & $\begin{array}{l}-18 * * * \\
(-24,-9)\end{array}$ & $\begin{array}{l}-13^{* * *} \\
(-20,-3)\end{array}$ & $\begin{array}{c}-8 \\
(-17,6)\end{array}$ & $\begin{array}{c}-2 \\
(-14,18)\end{array}$ & $\begin{array}{c}10 \\
(-10,48)\end{array}$ & $\begin{array}{c}24 \\
(-6,88)\end{array}$ \\
\hline
\end{tabular}


Table 6: Breaking Exchange Rate Commitments (excluding fixed exchange rates) and Government Fall

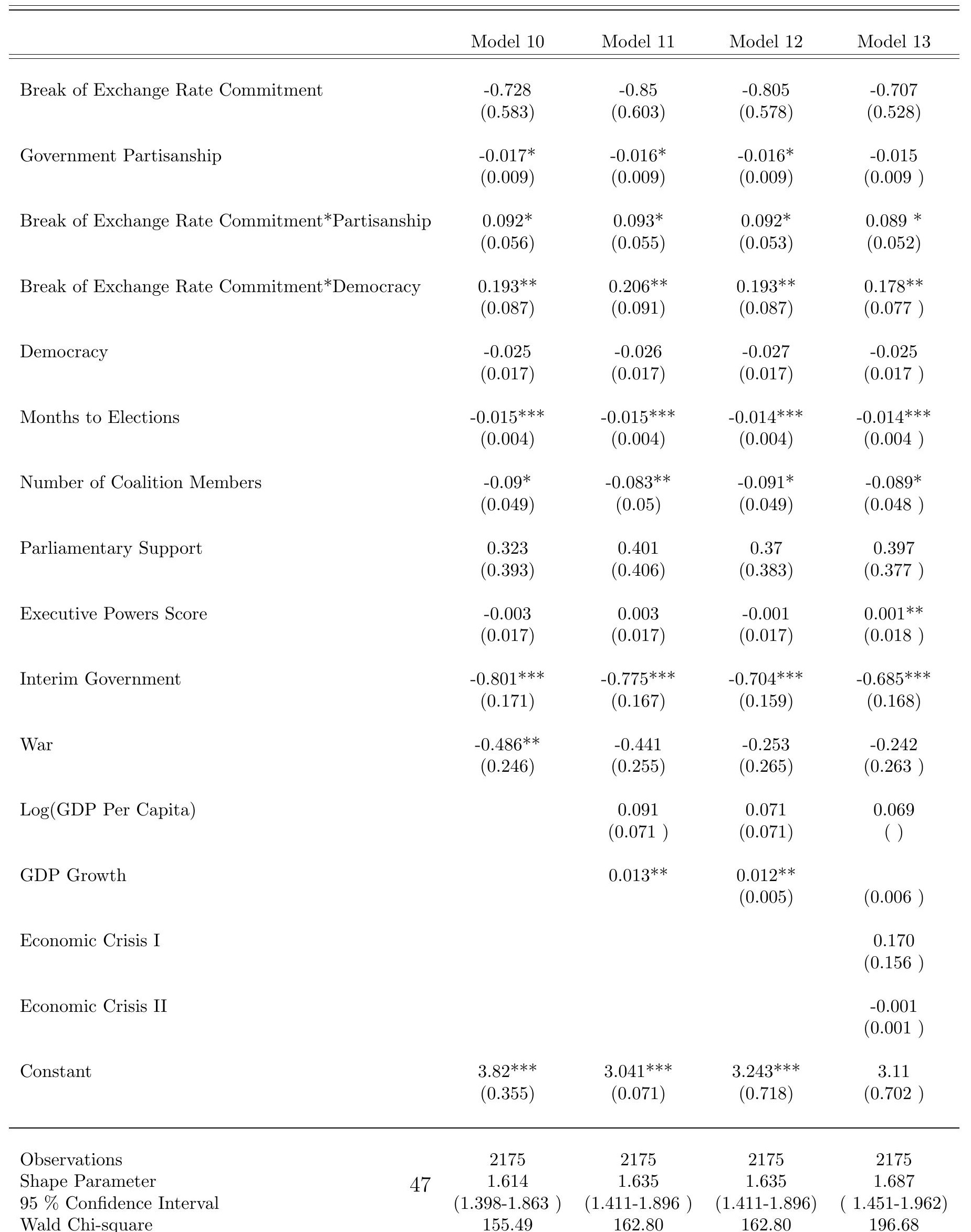


Table 7: Effect of Breaking Exchange Rate Commitments on Government Duration (Number of Months), First Differences

\begin{tabular}{lccccc}
\hline \hline \multirow{2}{*}{ Partisanship } & -10 (minimum) & -8.23 & -1.39 & 5.45 & 10 (maximum) \\
\hline \hline \multirow{2}{*}{ Model 10 } & & & & & \\
& -17 & -14 & -6 & 11 & 30 \\
Model 11 & $(10)$ & $(10)$ & $(9)$ & $(16)$ & $(36)$ \\
& -18 & -16 & -7 & 8 & 26 \\
Model 12 & $(9)$ & $(9)$ & $(8)$ & $(15)$ & $(31)$ \\
& $-17^{*}$ & $-16^{*}$ & -7 & 7 & 24 \\
Model 13 & $(9)$ & $(9)$ & $(8)$ & $(14)$ & $(28)$ \\
& $-17^{*}$ & -15 & -6 & 9 & 26 \\
& $(8)$ & $(8)$ & $(8)$ & $(14)$ & $(27)$ \\
\hline
\end{tabular}


Table 8: Summary Statistics

\begin{tabular}{lccccc}
\hline Variable & Number of observations & Mean & Standard Deviation & Minimum & Maximum \\
& & & & & \\
& & & & & \\
& & -1.29 & 6.83 & -10 & 10 \\
Government Partisanship & 2655 & 2.17 & 1.5 & 1 & 9 \\
Number of Coalition Members & 2655 & 0.52 & 0.25 & 0.06 & 1 \\
Parliamentary Support & 2655 & 2.98 & 6.35 & -9 & 10 \\
Democracy (Polity II) & 3468 & 7.23 & .89 & 5.75 & 9.32 \\
Log(GDP per capita) & 2884 & 8.93 & 5.84 & 1 & 21 \\
Executive Powers Score & 2336 & 24.95 & 15.14 & 1 & 60 \\
Months to Elections & 2655 & 0.08 & 0.27 & 0 & 1 \\
War & 2655 & .05 & .22 & 0 & 1 \\
Interim Government & 2667 & & & & \\
& & & & & \\
\hline
\end{tabular}

